\title{
Transaminase enzymes and lipid profiles and histological changes in Wistar rats after administration of bintangur (Calophyllum soulattri) leaves ethanolic extract
}

\author{
INARAH FAJRIATY", PRATIWI APRIDAMAYANTI, SUCI PUTRI RAHMAWANI" \\ Department of Pharmacy, Faculty of Medicine, Universitas Tanjungpura. J1. Prof. Hadari Nawawi, Pontianak 78121, West Kalimantan, Indonesia. \\ Tel.: +62-561-765342, 583865, 732500, Fax.: +62-561-765342, `email: inarah.fajriaty@yahoo.com, "v rahmawani_suciputri@yahoo.com
}

Manuscript received: 10 October 2017. Revision accepted: 27 January 2018.

\begin{abstract}
Fajriaty I, Apridamayanti P, Rahmawani SP, Abdurrachman. 2018. Transaminase enzymes and lipid profiles and histological changes in Wistar rats after administration of bintangur (Calophyllum soulattri) leaves ethanolic extract. Nusantara Bioscience 10: 2735. Bintangur (Calophyllum soulattri Burm. F) can be found in West Kalimantan and traditionally used as a medicine for treatment of wounds, inflammation, and rheumatism. Bintangur contains terpene derivatives, xanthones, coumarins, steroid derivatives, flavonoid and also saponins. The present study was conducted to determine the in vivo effect of oral administration of bintangur leaves ethanolic extract (BLEE) on transaminase and lipid profiles and histological changes in experimental rats. Eighty-four Wistar rats were divided into six groups; each group consisted of seven male and seven female rats. The first group was applied with CMC-Na $1 \%$ as a control. The second, third, and fourth group were applied with $100 \mathrm{mg} \mathrm{kg}^{-1} \mathrm{BW}, 400 \mathrm{mg} \mathrm{kg}^{-1} \mathrm{BW}, 1000 \mathrm{mg} \mathrm{kg}^{-1} \mathrm{BW}$ dose of BLEE respectively. The fifth and sixth group were the satellite for assessment of reversibility, persistence or delayed effects. The animals were given extract once daily for 28 days, while for the satellite groups still observed until 14 days. At the end of the study, all rats were sacrificed, and the blood and organs were collected for biochemical and histological examination. The result showed that BLEE increased transaminase profile, ALT, and AST, with the highest increase in $400 \mathrm{mg} \mathrm{kg}^{-1} \mathrm{BW}$ dose. But a significant increase (p<0.05) only found in AST profile of $400 \mathrm{mg} \mathrm{kg}^{-1} \mathrm{BW}$ dose in female rats. In lipid profile, BLEE did not affect cholesterol total, but caused significant decrease $(\mathrm{p}<0.05)$ in triglyceride profile of $1000 \mathrm{mg} \mathrm{kg}^{-1} \mathrm{BW}$ dose in male and female rats. In the histological assessment, obvious histological changes were observed in liver and heart. There had necrosis of hepatocytes cells of male and female rats with obvious changes in $1000 \mathrm{mg} \mathrm{kg}{ }^{-1} \mathrm{BW}$ dose and congestion of central vein of male rats in $400 \mathrm{mg} \mathrm{kg}^{-1} \mathrm{BW} \mathrm{dose} \mathrm{and} 1000 \mathrm{mg} \mathrm{kg}^{-1} \mathrm{BW}$ dose. In heart muscle fibers showed an irregular structure in $1000 \mathrm{mg} \mathrm{kg}^{-1} \mathrm{BW}$ dose of female rats. While observation of spleen showed no harmful changes in all groups. The conclusion of this study showed BLEE increase transaminase profile and some damaging effect on the liver and heart organ of Wistar rat but should be considered as an herbal medicine with potential effect as antihypertriglyceridemia.
\end{abstract}

Keywords: Calophyllum soulattri, ethanolic extract, lipid profile, histology, transaminase enzymes. Abbreviations: $\mathrm{BLEE}=$ Bintangur Leaves Ethanolic Extract, $\mathrm{BW}=$ Body Weight, $\mathrm{CMC}=$ Carboxymethyl cellulose, ALT $=$ Alanine
transaminase, $\mathrm{AST}=$ Aspartate transaminase

\section{INTRODUCTION}

Traditional medicine is an important part of health services and found in almost every country in the world. Safety, efficacy, and quality are key objectives to strengthen the role traditional medicine (WHO, 2013). Natural products serve as the lead compounds for the development of new medicine. Modern medicines contain the active substances with obvious identity and quantity as in contrast to traditional medicines which contain many unknown chemical substances and indeterminate effect, therapeutic or toxic effects. It is necessary to explore their uses and to conduct pharmacological studies to discover their therapeutic or toxic effect.

Bintangur (Calophyllum soulattri Burm. F) is one of the plants that used empirically as herbal medicine. Leaves steep is used for washing inflamed eyes, wound, burns, and skin care. Decoction of the stem bark for treatment of vagina wet mount and rheumatic. Seed oil is used for the treatment of scabies, ulcers, hair growth. Timbers steep is used as energizing herb (Budi et al. 2014). Previous studies of genus Calophyllum indicated the existence of a variety of secondary metabolites such as xanthones, coumarins, chromanone, biflavonoid, asilploroglusinol, triterpenoids and steroid which possess various bioactivities ( $\mathrm{Su}$ et al. 2008). Some of these biologically active compounds have also shown activity as anti-HIV (Laure et al. 2008), antifungal (Dharmaratne et al. 2009), repellant (Hieu et al. 2010), anti-inflammatory (Tsai et al. 2012), and anti-cancer (Mah et al. 2012).

Liver represents the largest gland in the body which occupies the first place get the effects of foreign compounds. Liver damage can be detected by measuring the increased level of liver transaminase enzymes, alanine transaminase (ALT) and aspartate transaminase (AST). ALT is more specific to liver damage than AST because 
AST also can be found in other tissues, such as the heart. Changes level of AST, in general, are often caused by liver disease, but also consider the possibility of heart disease (Salma et al. 2013). Liver is also the main route for synthesis and regulation of lipid metabolism. The level of total cholesterol and triglycerides are indicators used to diagnose damage regulation of lipid metabolism in the liver (Mandal et al. 2013). But in some theories, lipid metabolism also can be influenced by spleen condition of hypersplenism and splenomegaly (Goncalves et al. 2014).

This research was conducted to evaluate the effects of some levels of dose of bintangur ( $C$. soulattri) leaves ethanolic extract after prolonged use and are carried out to provide information about the effect and possible health hazards including information about target organs, the possibilities of cumulative effects and to find out the reversibility of any observed effects. Therefore, aim to investigate the effect of bintangur leaves ethanolic extract on transaminase enzymes and lipid profiles and histological changes in Wistar rats.

\section{MATERIALS AND METHODS}

\section{Study area}

In the present study, leaves of Calophyllum soulattri Burm. F. was collected from local area of Mandor forest, Landak district, West Kalimantan, Indonesia. The plant sample was authenticated in Biology Department, Faculty of Mathematics and Natural Sciences, Tanjungpura University, Pontianak, Indonesia.

\section{Procedures}

\section{Animals}

Adult female and male Wistar rats were used in the present study. They were healthy, no physical defects, body weight of 100-300 g, weight variation less than $20 \%$, unpregnant. They were housed in standard mouse cages under $22 \pm 3^{\circ} \mathrm{C}, 30-70 \%$ relative humidity, 12 hours of light and 12 hours of dark. Animals were given standard rat pellets and drinking water ad libitum.

\section{Extract preparation}

The leaves were shade dried and made into coarse powder and extracted by continuous extraction using Soxhlet apparatus and ethanol 96\%. After exhaustive extraction, the collected extract was dried under reduced pressure using rotary evaporator and dried at water bath.

\section{Phytochemical screening}

To determine the chemical constituent, qualitative phytochemical screening of BLEE was carried out following standard procedures routinely and revealed alkaloid (Mayer and Dragendoff test), phenol ( $\mathrm{FeCl}_{3} \quad 1 \%$ test), tannin $\left(\mathrm{FeCl}_{3} \quad 10 \%\right.$ and gelatin test), flavonoid (Shinoda test), steroid and terpenoid (LiebermannBurchard test), saponin (frothing test), and quinone (KOH $5 \%$ test).

\section{Experimental design}

Eighty-four Wistar rats were adapted for one week of acclimatization period and randomly assigned to six groups $(n=14)$, where there were seven males and seven females in each group. The first group was given with CMC-Na $1 \%$ as a control. The second, third, and fourth group were given with BLEE dissolved in CMC-Na $1 \%$ at concentrations of $100 \mathrm{mg} \mathrm{kg}^{-1} \mathrm{BW}, 400 \mathrm{mg} \mathrm{kg}{ }^{-1} \mathrm{BW}, 1000 \mathrm{mg} \mathrm{kg}^{-1} \mathrm{BW}$ respectively. The fifth and sixth group were controlled (CMC-Na 1\%) satellite and high-dose (1000 mg kg-1 BW) satellite respectively. The oral administrations were carried out for 28 days, the first to fourth group terminated and analyzed, while the satellite groups, the fifth and sixth group were still observed until 14 days during the postobservation period for assessment of reversibility, persistence or delayed effects. The body weights of rats were recorded daily during the study. Clinical observations for all rats were conducted by recording abnormal clinical signs or death. At the end of the studies, blood samples were collected through the heart and centrifuged to obtain serum (stored at $-20^{\circ} \mathrm{C}$ until analysis). The organs were carefully removed and weighted for histological and tissue analysis.

\section{Total cholesterol and triglycerides profiles analysis}

Total cholesterol and triglycerides profiles were measured by colorimetric enzymatic test, cholesterol oxidase phenol 4-aminoantipyrine peroxidase (CHODPAP) method and glycerol phosphate oxidase-paminophenazone (GPO-PAP) method.

\section{ALT and AST profiles analysis}

ALT and AST were measured by Optimized UV-test according to IFCC (International Federation of Clinical Chemistry and Laboratory Medicine)

\section{Histological and tissues analysis}

At the termination of the treatment period (day 29) and the end of recovery period (day 43), all rats were sacrificed, and complete necropsies were carried out. Necropsy was performed to analyze the macroscopic external features of organs. Organs (liver, heart, spleen, pancreas, lung, kidney, adrenal, gastric, brain, seminal vesicle and testes, uterus and ovaries) were carefully removed and weighed immediately for organ indexes analysis. While liver, heart, and spleen were fixed in neutral buffered formalin (BNF) $10 \%$ for histological analysis. Tissue samples were prepared routinely and cut into $3-5 \mathrm{~mm}$ and tissues were subjected to dehydration, clearing, embedding, blocking, and sectioning at 2-5 $\mu \mathrm{m}$ using rotary microtome and followed by hematoxylin-eosin staining. The observation of all tissue was performed on gross and microscopic bases then examined using a light microscope. Histological analysis was done according to the method described by Mescher (2014).

\section{Data analysis}

Data were expressed as mean \pm standard deviation for each group of animals at the number of Figures. Statistical 
analysis was performed using SPSS and evaluated at $5 \%$ ( $\mathrm{P}<0.05$ was considered statistically significant).

\section{RESULTS AND DISCUSSION}

\section{Phytochemical assay}

Phytochemical screening showed that ethanol extraction had more secondary metabolite substances. BLEE revealed the presence of the following classes of chemical substances: phenol, tannin, flavonoid, steroid/triterpenoid, and saponin.

\section{Body weight and general signs}

No death and sign of straub, piloerection, ptosis, lacrimation, catalepsy, salivation, vocalization, tremors, convulsion, and writhing throughout the treatment period of 28 days and also during recovery period. Pineal reflex, corneal reflex, hanging, establishment, flexion, haffner, grooming, defecation, urination, breathing were normal.
Motor activity in control and test group were comparable. There was a decrease in motor activity, but after 14 days in satellite group, motor activity returned to normal.

Body weight development profile between control and test group were comparable as shown in Figure 1. Body weight was found decreased to control throughout the treatment period. Observation in satellites high dose in male rats showed no reversible effect, but it found in female rats that body weight increased after stopped treated at $1000 \mathrm{mg} \mathrm{kg}^{-1} \mathrm{BW}$ at 29 days until 43 days.

\section{ALT and AST profiles}

BLEE caused an increase of ALT and AST in normal rats with the highest increase after treated $400 \mathrm{mg} \mathrm{kg}^{-1} \mathrm{BW}$ of BLEE. There was not a significant increase in the profile of $\operatorname{ALT}(p>0.05)$. But in the AST profile, there was a significant level increase in the female rat after treated with $400 \mathrm{mg} \mathrm{kg}^{-1} \mathrm{BW}$ of BLEE compared to control group. ALT and AST profiles are presented in Table 1.

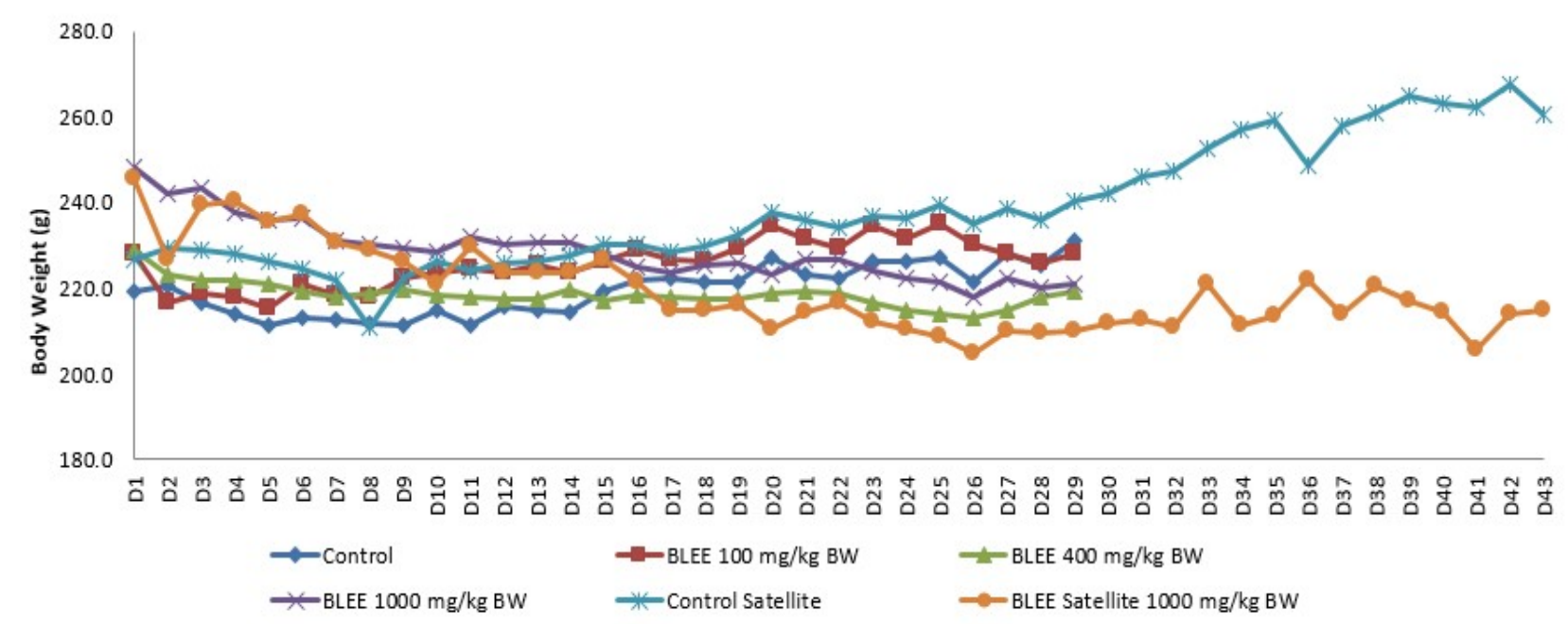

(A)

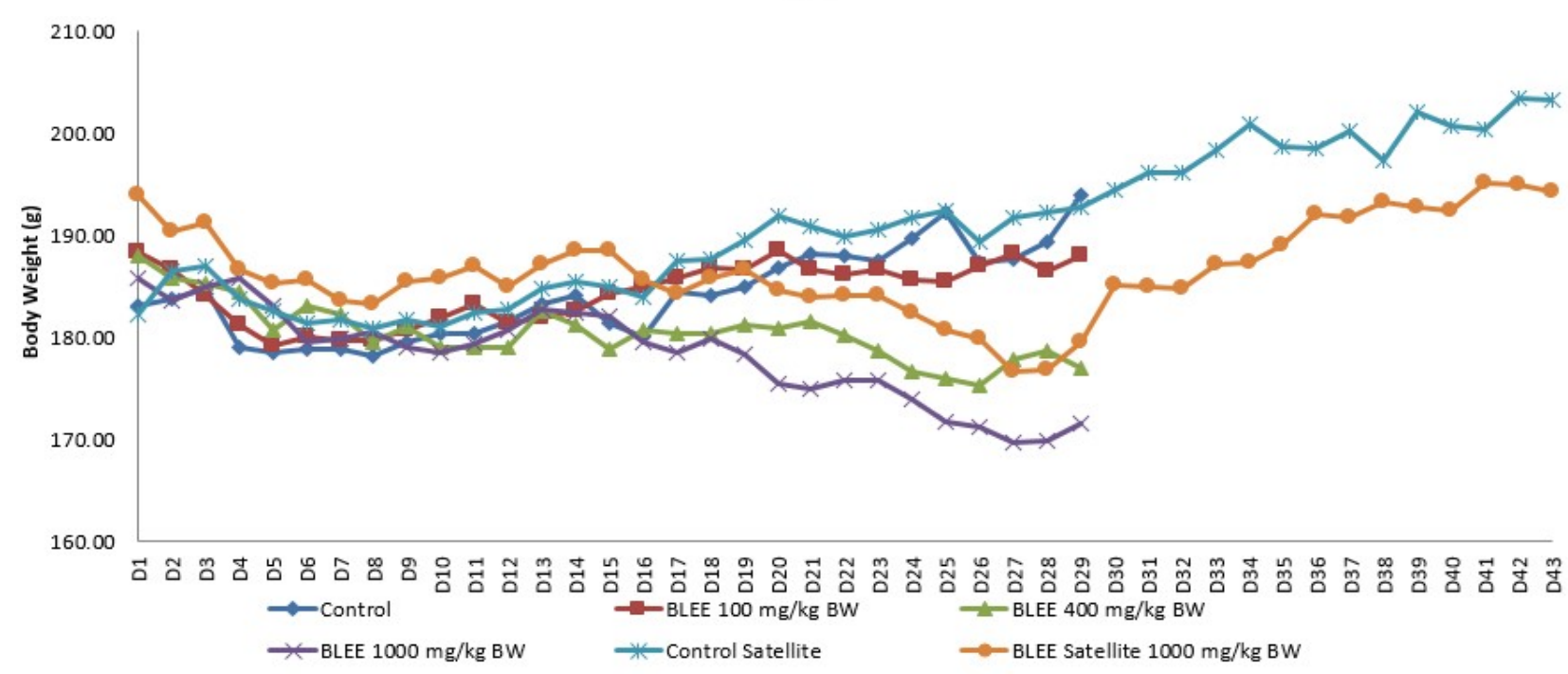

(B)

Figure 1. Body weight profile after oral administration of bintangur (Calophyllum soulattri) leaves ethanolic extract (BLEE), (A): Male; (B): Female 


\section{Total cholesterol and triglycerides profiles}

BLEE caused a decrease in total cholesterol and triglycerides in normal rats. There was not a significant decrease in the profile of total cholesterol ( $p>0.05)$. But in the triglycerides profile, there was significant level decrease after treated $1000 \mathrm{mg} \mathrm{kg}^{-1} \mathrm{BW}$ of BLEE compared to control group also after 14 days in high-dose satellite still caused a significant level decrease $(p<0.05)$ compared to control satellite group. Total cholesterol and triglycerides profiles are presented in Table 2.

\section{Histological and tissues profiles}

Macroscopic observation which included the shape and color of organs showed normal results and no alterations occurred between control group and test group. Organ index profile between control and test group were comparable (Figure 2). Significant different in organ index only found in liver in male rat which treated at $1000 \mathrm{mg} \mathrm{kg}^{-}$ ${ }^{1} \mathrm{BW}$ of BLEE $(\mathrm{p}<0.05)$ compared to control group and also after 14 days in high-dose satellite group compared to control satellite $(\mathrm{p}<0.05)$.

Histological observation was analyzed in the microscopic of liver, heart and spleen organs. The result of histological observation of liver showed in Figure 3. The group of BLEE $100 \mathrm{mg} \mathrm{kg}^{-1} \mathrm{BW}$ showed normal structures compared to the control group. Necrosis of hepatocytes cells found in the group of BLEE $400 \mathrm{mg} \mathrm{kg}^{-1} \mathrm{BW}$ and $1000 \mathrm{mg} \mathrm{kg}^{-1} \mathrm{BW}$ of male and female rats, with most obvious changes in BLEE $1000 \mathrm{mg} \mathrm{kg}^{-1} \mathrm{BW}$. Congestion of central vein found in the group of BLEE $400 \mathrm{mg} \mathrm{kg}^{-1}$ $\mathrm{BW}$ and $1000 \mathrm{mg} \mathrm{kg}^{-1} \mathrm{BW}$ of male rats.

The result of histological observation of heart showed in Figure 4. The group of BLEE $100 \mathrm{mg} \mathrm{kg}^{-1} \mathrm{BW}$ and 400 $\mathrm{mg} \mathrm{kg}{ }^{-1} \mathrm{BW}$ showed no alterations compared to the control group. While an irregular structure of heart muscle fibers found in the group of BLEE $1000 \mathrm{mg} \mathrm{kg}^{-1} \mathrm{BW}$.

The result of histological observation of spleen showed in Figure 5. Based on the observation, there were no alterations occur in histological of spleen. All groups of dose of BLEE showed normal structure compared to the control group.

\section{Discussion}

The present study used ethanol $96 \%$ as the solvent commonly that used for extraction of fresh samples. It can dissolve any substance, whether polar, semi-polar and nonpolar as well as its ability to precipitate proteins and inhibit the action of the enzyme. Besides, it can avoid hydrolysis and oxidation processes as well as having lower toxicity than other organic solvents such as methanol, chloroform, and hexane (Fajriaty et al. 2014).

During the study period, no mortality was observed. No abnormalities in behavior but there was a reversible decrease in motor activity. The decrease in motor activity can be manifested as the presence of sedative activity, muscle relaxants, paralysis, or anesthesia (Khan et al. 2014). Observation in body weight profile showed that the higher dose, the higher decrease in body weight. But in the assessment of reversibility, after stopped treated, there was a significant increase again in body weight. It means that effect of decrease of body weight was reversible with high reversible effect in female rats which alleged by an influence of hormones in female rats, so they had better immunity to some stress (Robert et al. 2011).

Table 1. ALT and AST profiles after oral administration of bintangur (Calophyllum soulattri ) leaves ethanolic extract (BLEE)

\begin{tabular}{|c|c|c|c|c|}
\hline \multirow{2}{*}{ Group } & \multicolumn{2}{|c|}{ ALT } & \multicolumn{2}{|c|}{ AST } \\
\hline & Male & Female & Male & Female \\
\hline Control & $60.50 \pm 18.63$ & $62.72 \pm 10.48$ & $126.92 \pm 18.75$ & $119.72 \pm 14.12$ \\
\hline BLEE $100 \mathrm{mg} \mathrm{kg}^{-1} \mathrm{BW}$ & $83.67 \pm 18.88$ & $83.24 \pm 15.99$ & $156.73 \pm 20.37$ & $157.10 \pm 18.25$ \\
\hline BLEE $400 \mathrm{mg} \mathrm{kg}^{-1} \mathrm{BW}$ & $84.07 \pm 16.07$ & $92.36 \pm 15.01$ & $158.47 \pm 18.46$ & $211.12 \pm 25.41^{*}$ \\
\hline BLEE $1000 \mathrm{mg} \mathrm{kg}^{-1} \mathrm{BW}$ & $61.55 \pm 14.48$ & $66.86 \pm 9.49$ & $139.50 \pm 16.54$ & $168.78 \pm 18.21$ \\
\hline Satellite (Control) & $60.98 \pm 15.01$ & $42.82 \pm 5.62$ & $151.20 \pm 19.51$ & $139.00 \pm 18.75$ \\
\hline Satellite (BLEE $1000 \mathrm{mg} \mathrm{kg}^{-1} \mathrm{BW}$ ) & $61.05 \pm 12.20$ & $56.85 \pm 7.49$ & $135.15 \pm 16.00$ & $144.20 \pm 10.83$ \\
\hline
\end{tabular}

Note: *Significant different from control group $(\mathrm{P}<0.05)$

Table 2. Total cholesterol and triglycerides profiles after oral administration of bintangur (Calophyllum soulattri ) leaves ethanolic extract (BLEE)

\begin{tabular}{ccccc}
\hline \multirow{2}{*}{ Group } & \multicolumn{2}{c}{ Total cholesterol } & \multicolumn{2}{c}{ Triglycerides } \\
\cline { 2 - 5 } Montrol & Male & Female & \multicolumn{2}{c}{ Female } \\
\hline BLEE100 mg kg-1 BW & $102.32 \pm 13.56$ & $108.77 \pm 5.84$ & $177.78 \pm 23.62$ & $182.40 \pm 8.71$ \\
BLEE 400 mg kg ${ }^{-1} \mathrm{BW}$ & $99.76 \pm 7.42$ & $112.90 \pm 18.62$ & $171.00 \pm 17.80$ & $179.17 \pm 4.91$ \\
BLEE 1000 mg kg $\mathrm{BW}$ & $100.12 \pm 14.28$ & $105.20 \pm 15.54$ & $165.62 \pm 10.04$ & $178.40 \pm 10.45$ \\
Satellite (Control) & $98.34 \pm 15.66$ & $97.88 \pm 15.94$ & $136.28 \pm 10.46^{*}$ & $155.66 \pm 14.08^{*}$ \\
Satellite (BLEE 1000 mg kg BW) & $100.87 \pm 7.88$ & $98.37 \pm 5.03$ & $144.37 \pm 7.84$ & $195.90 \pm 9.91$ \\
\end{tabular}

Note: *Significant different from control group $(\mathrm{P}<0.05) . \wedge$ Significant different from control satellite group $(\mathrm{P}<0.05)$ 


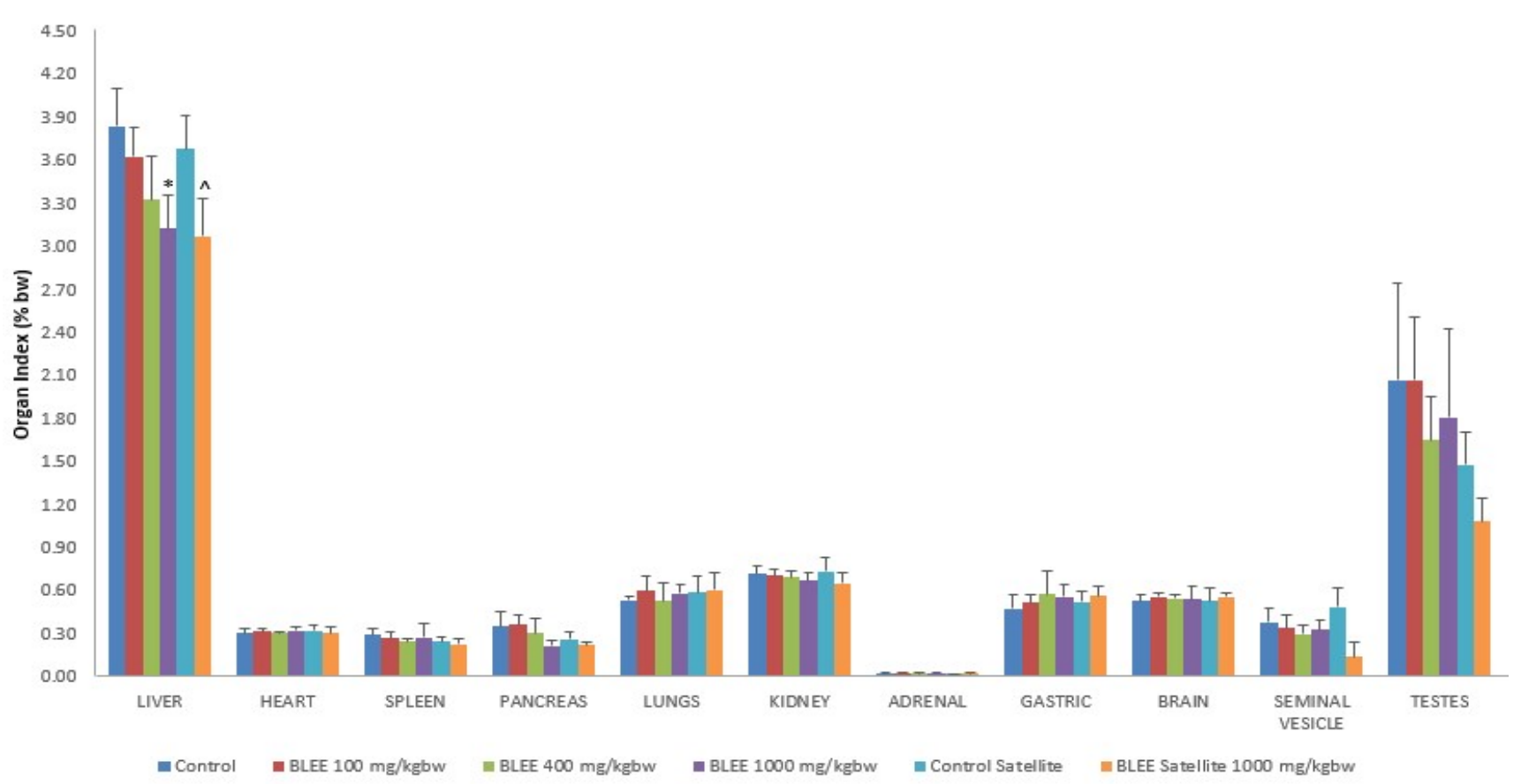

A

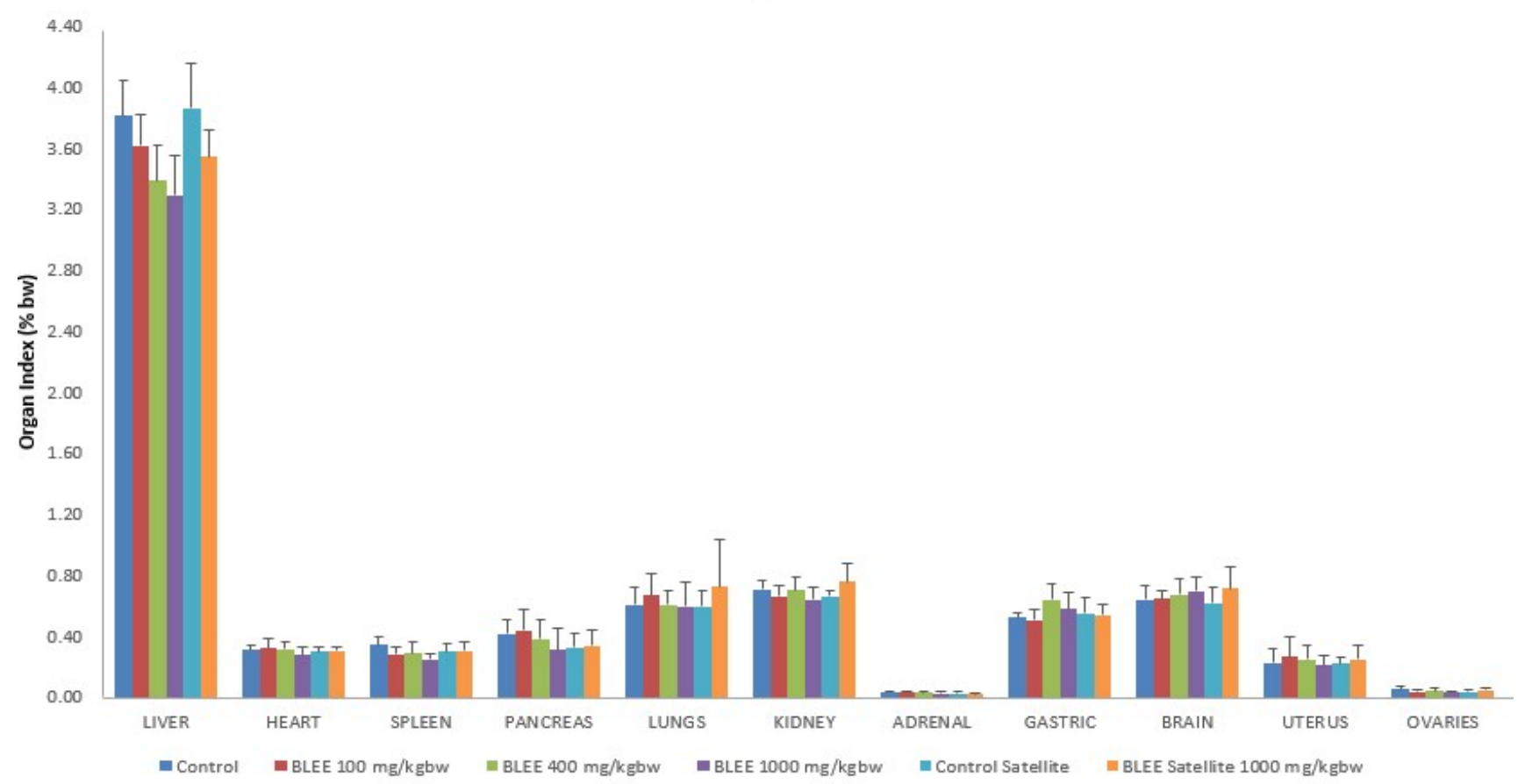

B

Figure 2. Organ Index profile after oral administration of bintangur (Calophyllum soulattri ) leaves ethanolic extract (BLEE), (A): Male; (B): Female, *Significant different from control group $(\mathrm{P}<0.05),{ }^{\wedge}$ Significant different from control satellite group $(\mathrm{P}<0.05)$

The Plasma level of transaminases is sensitive indicators of liver cell injury. Transaminase enzymes include ALT and AST are normally predominantly contained within liver cells, if liver is injured, the liver cells spill these enzymes into the circulation, raising ALT and AST enzyme blood levels (Mohd et al. 2013). ALT was specific liver enzyme found in large amount in the liver. While AST was found in many tissues like heart, liver, kidney, brain, and skeletal muscle with the highest specific activity of the enzyme AST is found in the heart (Adaramoye et al. 2008). The increased level of ALT and AST were observed in all doses treatment with the highest increase in the mid-dose group treated with $400 \mathrm{mg} \mathrm{kg}^{-1}$ BW of BLEE. But, significant increase only found in AST of female rats after treated with $400 \mathrm{mg} \mathrm{kg}^{-1} \mathrm{BW}$ of BLEE. It is assumed that the targeted receptors have fulled of 400 $\mathrm{mg} \mathrm{kg}{ }^{-1} \mathrm{BW}$ of BLEE and addition of higher dose up to $1000 \mathrm{mg} \mathrm{kg}^{-1} \mathrm{BW}$ is deposited to other receptors. 

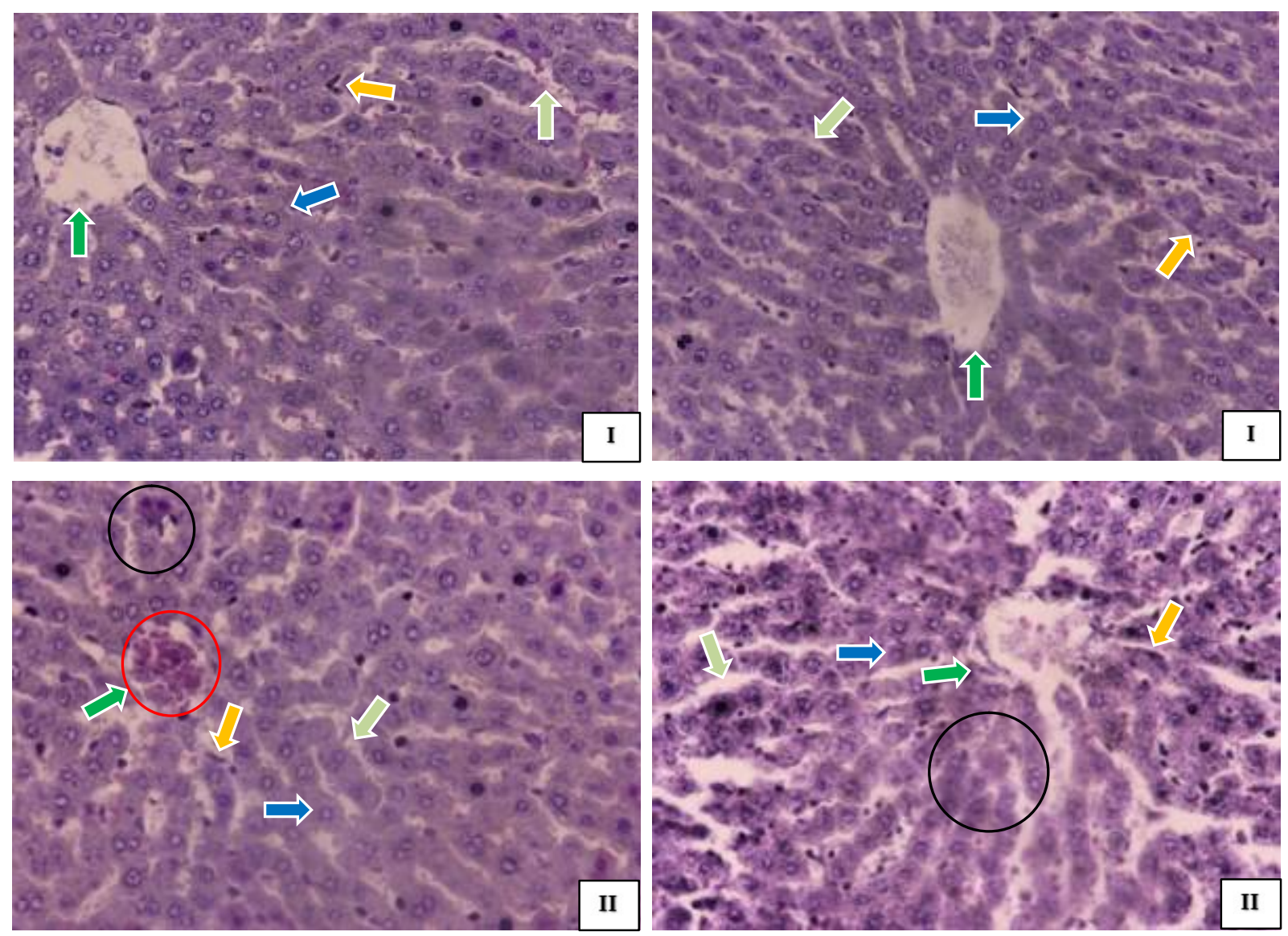

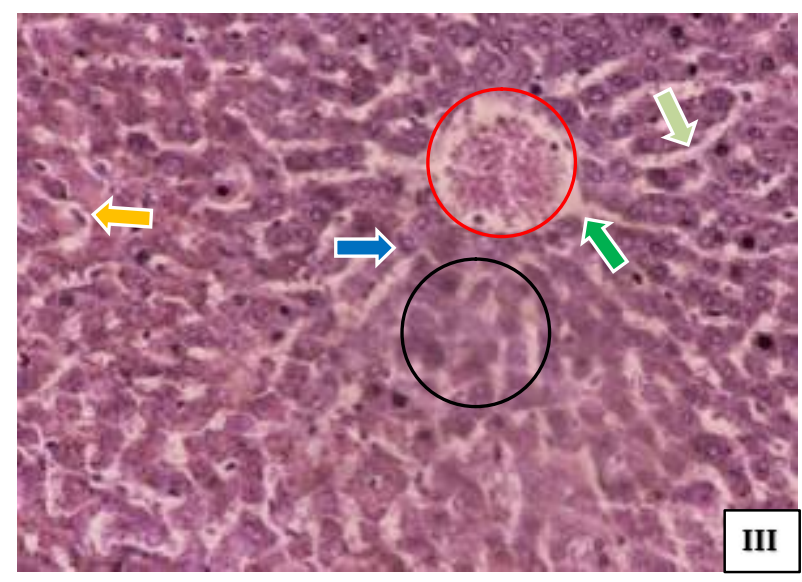

(A)

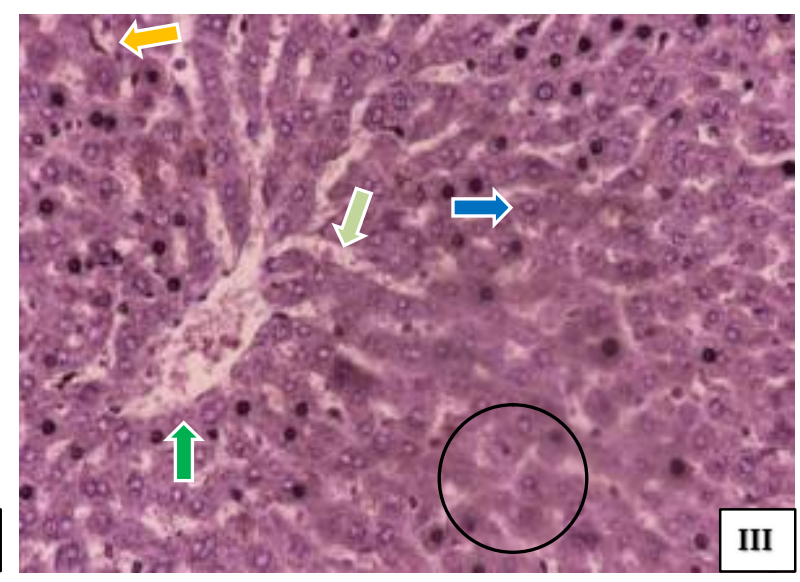

(B)

Figure 3. Photomicrograph of liver of control (I), BLEE $400 \mathrm{mg} \mathrm{kg}^{-1} \mathrm{BW}$ (II), BLEE $1000 \mathrm{mg} \mathrm{kg}^{-1}$ BW (III), (A) Male; (B) Female, $\rightarrow$ Hepatocytes; $\rightarrow$ Central Vein, $\Rightarrow$ Sinusoid, $\Rightarrow$ Kupffer Cell, $\bigcirc$ Necrosis, $\bigcirc$ Congestion

The level of total cholesterol and triglycerides are indicators used to diagnose regulation of lipid metabolism. Liver has main role in synthesis and lipid metabolism (Mandal et al. 2013). There were also a few theories to explain the role of spleen in the regulation of plasma lipids. Spleen can influence lipid metabolism through the B lymphocytes which were capable of producing antioxidized-LDL antibodies and remove it from the circulation by tissue macrophages (Goncalves et al. 2014). There was no effect on the level of total cholesterol, but there was decrease effect on triglycerides profile. Observation in triglycerides level showed significant decrease level after treated with $1000 \mathrm{mg} \mathrm{kg}^{-1} \mathrm{BW}$ of BLEE. It is possible that BLEE has antihypertriglyceridemia activity. 

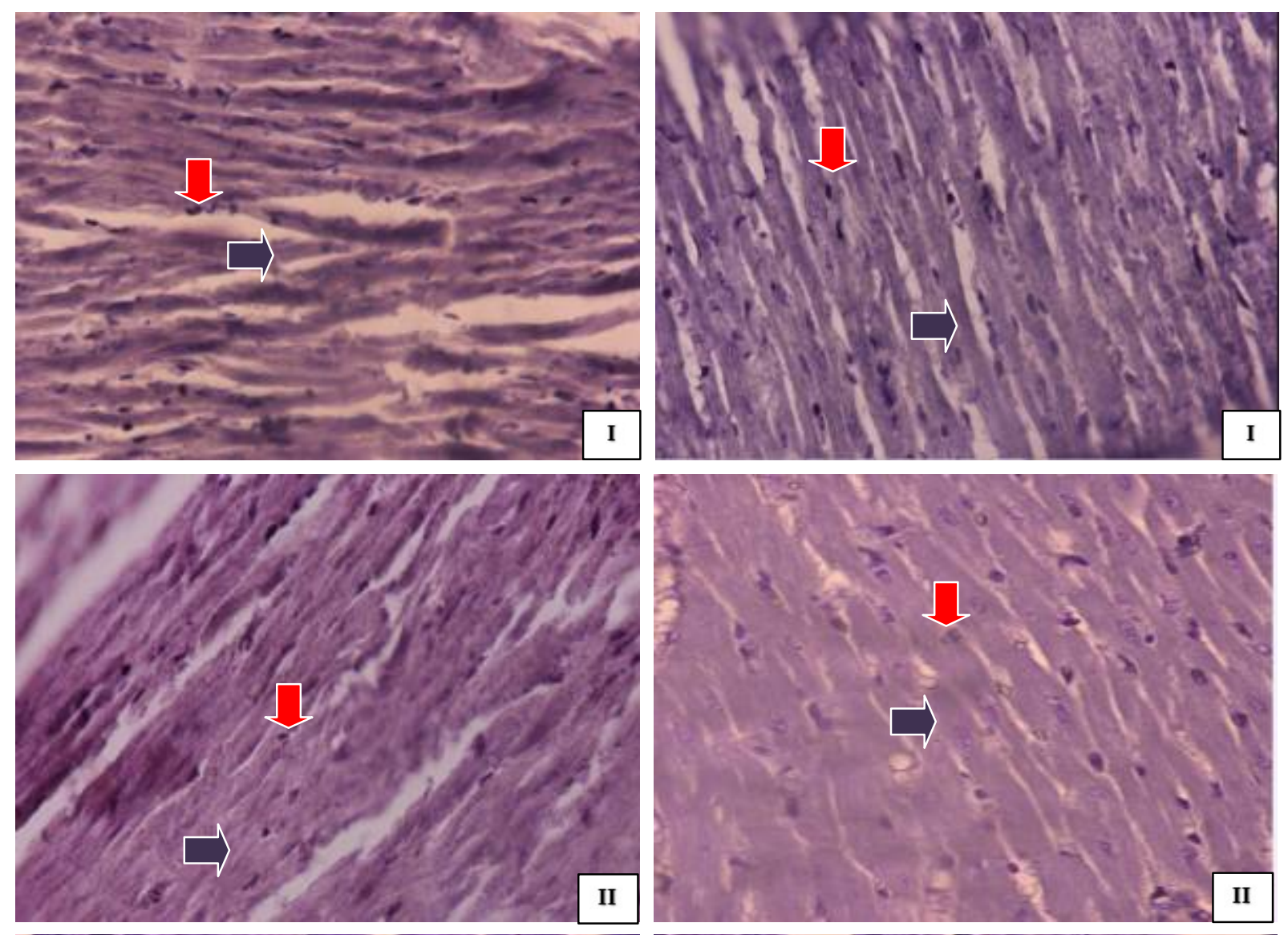

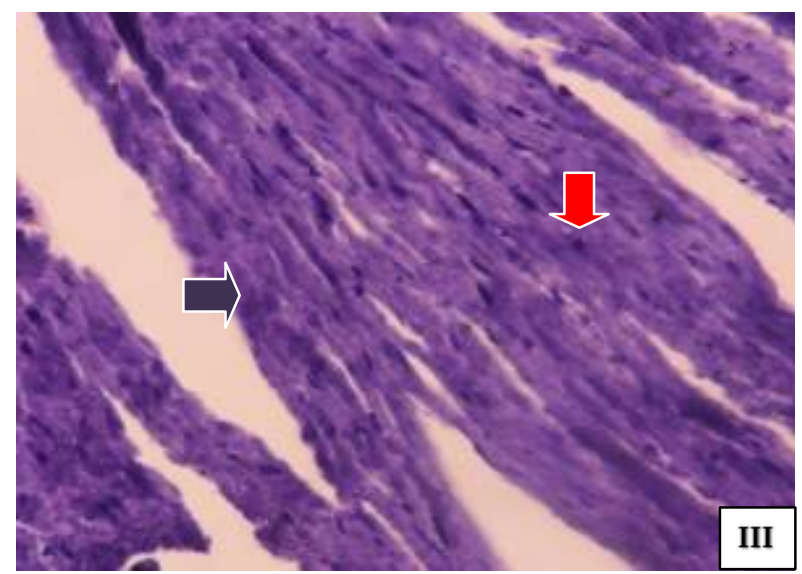

(A)

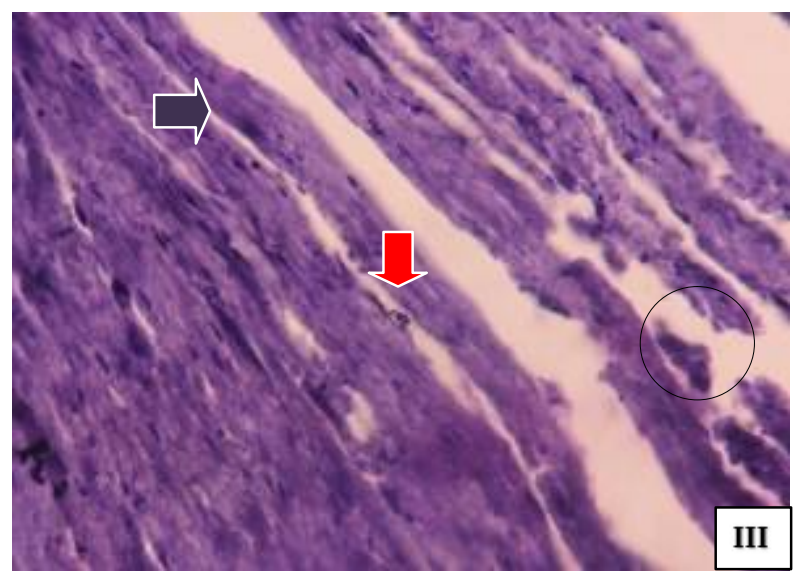

(B)

Figure 4. Photomicrograph of heart of control (I), BLEE $400 \mathrm{mg} \mathrm{kg}^{-1} \mathrm{BW}$ (II), BLEE $1000 \mathrm{mg} \mathrm{kg}^{-1} \mathrm{BW}$ (III), (A) Male; (B) Female, $\rightarrow$ Muscle Fiber; $\rightarrow$ Nucleus, OIrregular muscle fiber

The histological assessment further confirmed damage or improvement of organ function. Overall, in macroscopic observation showed that BLEE does not induce detrimental change and morphological alterations. The only alteration observed in organ index of the liver in male rats. There was significant decrease in organ index of the liver in male rats. Obvious histological change was observed in liver and heart, but it was reversible because observation satellite group after 14 days showed improvement. There were alterations in microscopic presentation in liver compared to the control group. There was necrosis of hepatocytes cells of male and female rats with obvious changes in the high- dose group (1000 mg kg-1 $\mathrm{BW}$ ) and congestion of central vein of male rats in mid and high-dose group (400 and $1000 \mathrm{mg} \mathrm{kg}^{-1} \mathrm{BW}$ ). There was kupffer cell in sinusoidal spaces which might indicate the absence of pathological changes in the liver. Histological condition of livers characterized by vacuolations, varying shapes and sizes of nuclei in hepatocytes, loss of sinusoidal spaces, inflammatory cells scattered all over hepatic tissue and there will be dilated of hepatic tissue, and there will be dilated of central vein filled with blood (Fajriaty et al. 2014). Heart muscles have regular pattern of fine parallel linear fibers giving the muscles their distinctive striated 
appearance (Lindskog et al. 2015). Observations in male rats actually showed no alterations in the cell nucleus and heart muscle fibers. While in female rats showed alteration in heart muscle fibers that irregular structure occurred in the high-dose group (1000 $\left.\mathrm{mg} \mathrm{kg}^{-1} \mathrm{BW}\right)$. In histology of spleen, there were not proliferation of white and red pulp; no changes were compared with the control group. Red pulp consisting of macrophage cells, plasma cells, and blood elements; and the white pulp consisting of lymphocytes which are densely arranged in it and the central artery in the middle, and there was no expansion of the germinal center (Mescher 2014). One of active metabolite in BLEE that indicated has main role saponin. Several other plants containing saponins have been shown to be hepatotoxic and increased ALT and AST serum level. Saponin also caused hemolysis and lower cell surface pressure, lead damage to heart muscle tissues cell (Maes 2013). Besides, saponin decreased cholesterol and triglycerides serum level; it inhibited absorption of cholesterol and pancreatic lipoprotein lipase (Kamesh 2012).
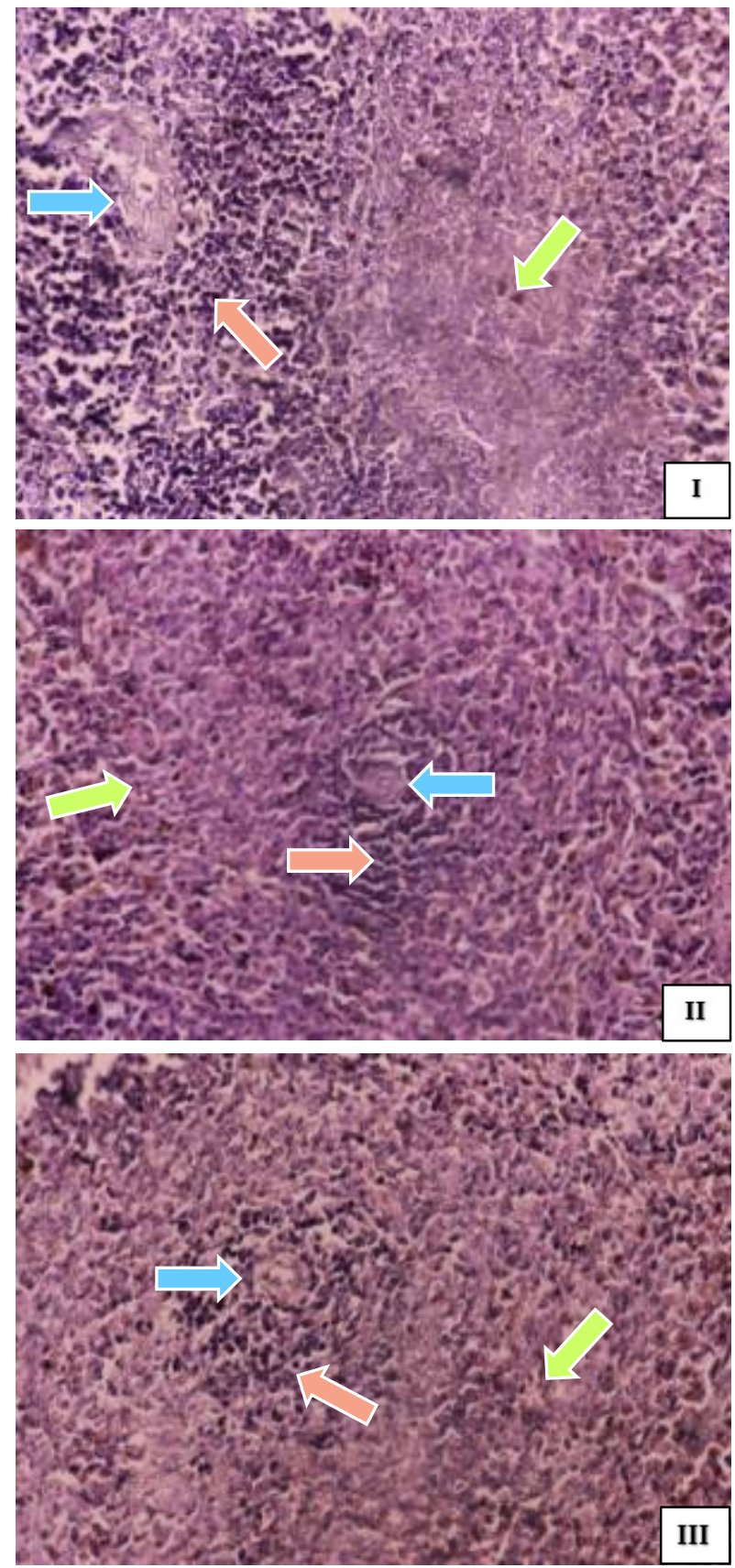

(A)
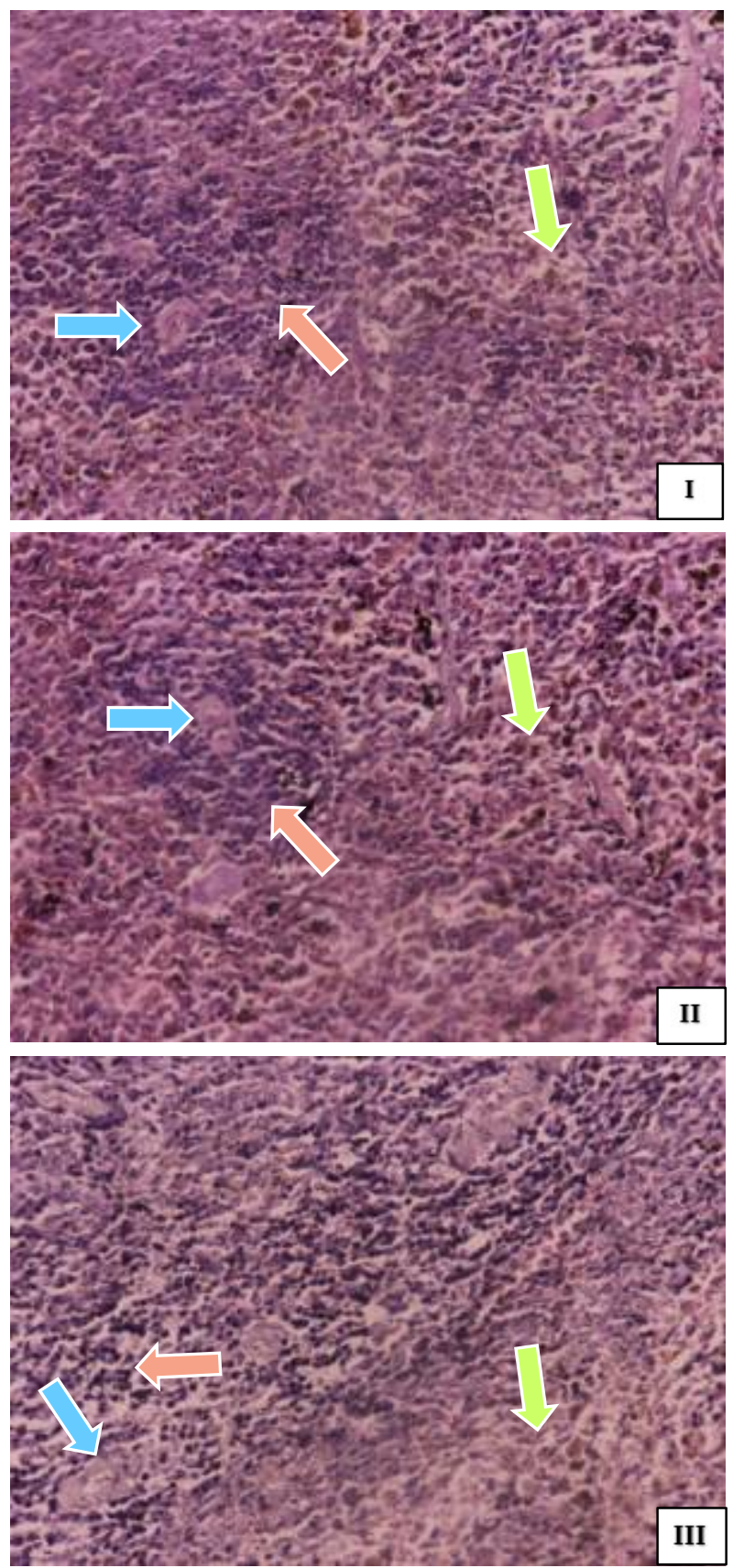

(B)

Figure 5. Photomicrograph of spleen of control (I), BLEE $400 \mathrm{mg} \mathrm{kg}^{-1} \mathrm{BW}$ (II), BLEE $1000 \mathrm{mg} \mathrm{kg}^{-1} \mathrm{BW}$ (III), (A) Male; (B) Female,

$\Rightarrow$ White Pulp (Lymphatic Nodules); $\rightarrow$ Red Pulp, $\rightarrow$ Central Artery 


\section{ACKNOWLEDGEMENTS}

This research was funded by Hibah DIPA 2016 by Ministry of Research, Technology and Higher Education of Indonesia.

\section{REFERENCES}

Adaramoye OA, Osaimoje DO, Akinsaya MA, Nneji CM, Fafunso MA Ademowo OG. 2008. Changes in antioxidant status and biochemical indices after acute administration of artemether, artemetherlumefantrine and halofantrine in rats. Basic Clin Pharmacol Toxicol 102: 412-418.

Budi L, Eritrina W, Maria H. 2014. Cultivation of Nyamplung. Ministry of Environment and Forestry Republic of Indonesia. www.litbang.dephut.go.id.

Dharmaratne HR, Napagoda MT, Tennakoon SB. 2009. Xanthones from roots of Calophyllum thwaitesii and their bioactivity. Nat Prod Res 23: 539-545.

Fajriaty I, I Ketut A, and Irda F. 2014. Acute and sub-chronic (28 days) repeated oral toxicity test of ethanol extract of lerak (Sapindus Rarak. Dc) Fruits in Wistar Rats.Int J Pharm Pharm Sci 6 (11): 487-492 2014.

Goncalves TB, Yamaki VN, Feijo DH, Almeida LE, Silveira E, Henriques $\mathrm{MV}$, et al. 2014. Effects of splenic allograft in lipid profile of nonsplenectomized rats: the immune and metabolic role of the "double spleen". Rev Col Bras Cir 41(2): 122-127.

Hieu TT, Kim SI, Kwon HW, Ahn YJ. 2010. Enhanced repellency of binary mixtures of Zanthoxylum piperitum pericarp steam distillate or Zanthoxylum armatum seed oil constituents and Calophyllum inophyllum nut oil and their aerosols to stomoxys calcitrans. Pest Manag Sci 66: 1191-1198.

Kamesh V and Thangarajan S. 2012. Antihypercholesterolemic effect of Bacopa monniera on high cholesterol diet-induced hypercholesterolemia in rats. Asian Pac J Trop Med 949-955.
Khan IN, Sarker MI, and Ajrin M. 2014. Sedative and anxiolytic effects of ethanolic extract of Calotropis gigantea (Asclepiadaceae) leaves. Asian Pac J Trop Biomed 4(1): 400-404.

Laure F, Raharivelomanana P, Franc J, Butaud O, Bianchini JP, Gaydou EM. 2008. Screening of Anti-HIV ${ }^{-1}$ Inophyllums by HPLC-DAD of Calophyllum inophyllum Leaf Extracts from French Polynesia Islands. Anal Chim Acta 624: 147-153.

Maes L. 2013. Intravenous and Subcutaneous Toxicity and Absorption Kinetics in Mice and Dogs of the Antileishmanial Triterpene Saponin PX-6518. Molecules 18: 4803-4815.

Mah SH, Ee GCL, Teh SS, Rahmani M, Lim YM, Go R. 2012. Phylatrin, A New Cytotoxic Xanthone from Calophyllum soulattri. Molecules 17: 8303-8311.

Mandal SK, Sil K, Chatterjee S, Ganguly J, Chatterjee K, Sarkar P, et al. 2013. A study on lipid profiles in chronic liver diseases. Natl J Med Res 3(1): 70-72.

Lindskog C, Linne J, Fagerberg L et al. 2015. The human cardiac and skeletal muscle proteomes defined by transcriptomics and antibodybased profiling. BMC Genomics 16: 475

Mescher AI. Junqueira's. 2014. Basic Histology: text and atlas. $14^{\text {th }}$ ed. Boston: The McGraw-HillCompanies Inc.

Mohd AH, Marghoob H, Abdelmarouf HM. 2013. Comparative levels of ALT, AST, ALP, and GGT in liver associated diseases. Euro J. Exp. Bio 3(2): 280-284.

Robert R, Ghazali DA, Favreau F, Mauco G, Hauet T, Goujon JM. 2011. Gender difference and sex hormone production in rodent renal ischemia-reperfusion injury and repair. $\mathrm{J}$ Inflamm 8(14). https://doi.org/10.1186/1476-9255-8-14

Salma Mahaboob R, Jayarami Reddy U, John Basha S. 2013. A study on serum enzyme levels in various liver diseases. Int J Med Res Health Sci 2(3): 395-398.

Su XH, Zhang, ML, Li, LG, Huo, CH, Gu, YC and Shi, QW. 2008. Chemical constituents of the plants of the genus Calophyllum. Chemistry and Biodiversity 5: 2579-2608.

Tsai SC, Liang YH, Chiang JH, Liu FC, Lin WH, Chang SJ, et al. 2012. Anti-inflammatory effects of Calophyllum inophyllum 1. In RAW264.7 cells. Oncol Rep 28: 1096-1102.

World Health Organization. 2013. WHO traditional medicine strategy 2014-2023.Geneva: World Health Organization. 